\title{
Diffusion Control and Metallurgical Behavior of Successive Buttering on SA508 Steel Using Ni-Fe Alloy and Inconel 182
}

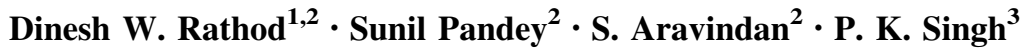

Received: 3 July 2016/ Accepted: 22 August 2016/Published online: 22 September 2016

(C) The Author(s) 2016. This article is published with open access at Springerlink.com

\begin{abstract}
The metallurgical deterioration and carbon diffusion caused during welding in the vicinity of the fusion interfaces between dissimilar metals have been investigated in case of gas tungsten arc and shielded metal arc welded SA508Gr.3Cl.1 steel substrate with $\mathrm{Ni}-\mathrm{Fe}$ alloy and Inconel 182. The study was conducted to investigate the effect of Ni-Fe matrix as buffer layer and SMAW process for buttering deposition on the carbon diffusion and metallurgical changes. Quantitative measurement and validation of carbon/alloying elements distribution in as-welded, thermally aged, and postweld heat-treated conditions were performed in buttering deposits by using optical emission spectrometry and electron probe microanalysis. The extent of carbon diffusion has been estimated using Groube's diffusion couple and confirmed with microstructure microhardness and X-ray diffraction. Martensite formation has been estimated for its thickness and validated with metallurgical properties. The effect of buffer layer is significant for carbon diffusion and tempering of martensite with thermal aging, PWHT, and multipass deposition. The concentration and activity gradient of carbon has been established due to Ni-Fe matrix as buffer layer and higher dilution for buttering. The obtained results are confirming the control of carbon diffusion and
\end{abstract}

Dinesh W. Rathod

dineshvrathod@gmail.com

1 Present Address: MTRL, School of MACE, University of Manchester, Manchester M1 3BU, UK

2 Department of Mechanical Engineering, Indian Institute of Technology Delhi, New Delhi 110016, India

3 Reactor Safety Division, Bhabha Atomic Research Centre, Mumbai 400085, India lesser metallurgical deterioration in suggested buttering procedure.

Keywords Carbon diffusion - Martensite layer · Fusion interface $\cdot$ Buffer layer $\cdot$ Buttering $\cdot$ Dissimilar weld

\section{Introduction}

Dissimilar metal welds (DMWs) are indispensable weld joints in nuclear plants, refineries, and petrochemical industries. The ferritic steel components are usually welded with stainless steel components using Inconel 82/182 consumables. To reduce the risk of sensitization during postweld heat treatment (PWHT) in stainless steel (as a joint) and maintaining metallurgical compatibility, the lowalloy ferritic steel is often welded with Ni-base overlays. This weld overlay is termed as buttering and commonly employed with gas tungsten arc welding (GTAW). The buttered (welded) ferritic steel in PWHT/as-buttered condition is then used for production of DMW with stainless steel. Inconel 82/182 fillers are expected to reduce the formation of decarburized region in ferritic steel and carburization in austenitic stainless steel [1-9] due to reduced diffusivity of carbon in Ni-matrix.

Unfortunately, the carbon diffusion is not completely arrested yet using Ni-base fillers [1, 6, 8, 10-15] as the significant amount of carbide formers $(\mathrm{Cr}, \mathrm{Nb}, \mathrm{Ti})$ exists in Inconel 82/182 fillers [11, 13, 14, 16, 17]. Effect of carbide formers in buttering using Inconel 82 fillers for the carbon diffusion and metallurgical deterioration has been investigated in previous study [16] using buffer layer ( $\mathrm{Ni}-\mathrm{Fe}$ alloy) free of carbide formers adjacent to ferritic steel. Subsequent buttering on buffer layer was made with low heat input gas metal arc welding (GMAW) [16]. Presence 
of carbide formers in considerable fractions in Inconel 82/182 buttering adjacent to SA508Gr.3cl.1 cannot ascertain the complete holdup to carbon diffusion $[1,6,8,11,15,17]$ and subsequent metallurgical deterioration [18] in terms of martensite and undesirable phase formation. Therefore, the effect of graded composition $[16,17,19]$ using $\mathrm{Ni}-\mathrm{Fe}$ alloy as intermediate buffer layer on ferritic steel with subsequent buttering using shielded metal arc welding (SMAW) was investigated. The SMAW process is well known for cheaper, faster, and high dilution against the traditionally preferred GTAW. Most of DMWs have performed almost $33-40 \%$ of their designed life $[1,9,11,20]$ due to several failure mechanisms of which carbon migration and metallurgical deteriorations are addressed here. Control of carbon migration and metallurgical deterioration can facilitate to increase the designed service life of DMWs. In the present work, the obtained results suggest the control of carbon diffusion and metallurgical deterioration at fusion interfaces, buffer layer, and buttering of DMWs.

\section{Materials and Methods}

\section{Experimental Procedure}

The SA508Gr.3cl.1 low-alloy ferritic steel of fully bainitic microstructure was used in the study and that was quenched and tempered in as-received condition. The plate $(150 \times 50 \times 15 \mathrm{~mm}$ size $)$ was machined from pipe section. The ERNiFe-CI-type Ni-Fe alloy (TIG rods) fillers of $\phi 2.4 \mathrm{~mm}$ and ENiCrFe-3-type Inconel 182 consumable were used in buttering to deposit buffer and buttering layer, respectively. The chemical composition of base metal SA508 ferritic steel and filler metals is given in Table 1.

The tungsten electrode of $\phi 3 \mathrm{~mm}$ was used with straight polarity to deposit the $\mathrm{Ni}-\mathrm{Fe}$ buffer layer using argon gas shielding at $9 \mathrm{~L} / \mathrm{min}$ by GTAW. The subsequent buildup of three buttering layers was employed with SMAW process using Inconel 182 ( $\phi 3.2 \mathrm{~mm}$ ) electrode and reverse polarity. The buttering procedure employed manually in both processes. The low dilution of $\mathrm{Ni}-\mathrm{Fe}$ alloy with ferritic steel substrate in buffer layer due to GTAW process can ensure the resulting weld chemistry of $\mathrm{Ni}-\mathrm{Fe}$ matrix in order to attain reduced diffusivity of carbon in Ni-matrix [1, 2] and graded composition [17, 19] in dissimilar welds. The process parameters used for buttering procedure to employ buffer and buttering layers are given in Table 2. Schematic of buffer and buttering layers and the as-buttered (as-welded) ferritic steel substrate with buttering deposit is shown in Fig. 1. The as-buttered weld pad with buttering deposit was cut in four sections to offer PWHT and thermal aging.

One section in as-buttered, one in PWHT condition, while rest two sections were used for thermal aging at 330 and $450{ }^{\circ} \mathrm{C}$. The phase transformation kinetics at $330{ }^{\circ} \mathrm{C}$ (service temperature $310-330{ }^{\circ} \mathrm{C}$ for such DMWs) and higher temperature $450{ }^{\circ} \mathrm{C}$ (that ensure the carbide precipitation [21]) were used with aging time [16, 21] of $240 \mathrm{~h}$.

The buttered ferritic steel is often associated with stress relief PWHT at $610{ }^{\circ} \mathrm{C}$ for 90 min prior to the weld joint fabrication, and this PWHT has been given to the one section from weld pad.

\section{Test Procedures and Methods}

The contamination-free specimens were prepared from different sections of weld pad by polishing up to Grade-I alumina, and such specimens were used for different measurements in the study. The electron microprobe was used for recording the wavelength-dispersive spectra (WDS) with accelerating voltage of $20 \mathrm{kV}$, counting time of $85 \mathrm{~s}$ and one measurement at every $15 \mu \mathrm{m}$ for total length of $1110 \mu \mathrm{m}$.
Table 1 Chemical composition base metal and filler metals

\begin{tabular}{llllllll}
\hline Elemental composition in weight percentage (wt\%) & & & & & & \\
\hline Material & $\mathrm{C}$ & $\mathrm{Cr}$ & $\mathrm{Ni}$ & $\mathrm{Fe}$ & $\mathrm{Mn}$ & $\mathrm{Nb}$ & $\mathrm{Mo}$ \\
\hline SA508Gr.3cl.1 steel & 0.197 & 0.12 & 0.53 & 96.95 & 1.30 & - & 0.44 \\
Ni-Fe alloy (ERNiFe-CI) & 0.025 & - & 53.01 & 43.24 & 0.73 & \multicolumn{1}{l}{-} & - \\
Inconel 182 (ENiCrFe-3) & 0.030 & 14.26 & 62.51 & 9.71 & 9.08 & 1.86 & 0.59 \\
\hline
\end{tabular}

Table 2 Process parameters during buttering operation for buffer and buttering layers

\begin{tabular}{lllllllll}
\hline Filler metal & Process & Layers & $\begin{array}{l}\text { No. of } \\
\text { passes }\end{array}$ & $\begin{array}{l}\text { Current } \\
(\mathrm{amps})\end{array}$ & $\begin{array}{l}\text { Voltage } \\
(\mathrm{V})\end{array}$ & $\begin{array}{l}\text { Thickness } \\
(\mathrm{mm})\end{array}$ & $\begin{array}{l}\text { Welding speed } \\
(\mathrm{mm} / \mathrm{sec})\end{array}$ & $\begin{array}{l}\text { Heat input } \\
(\mathrm{KJ} / \mathrm{mm})\end{array}$ \\
\hline Ni-Fe alloy & GTAW & Buffer & 4 & 100 & $9-11$ & 1.60 & 0.54 \\
Inconel 182 & SMAW & 2-4 Buttering & 3 & 85 & $26-28$ & $1.55-1.70$ & $1.45-1.57$ & $1.46-1.58$ \\
\hline
\end{tabular}


Fig. 1 Schematic of buttering deposit and the as-buttered ferritic steel substrate

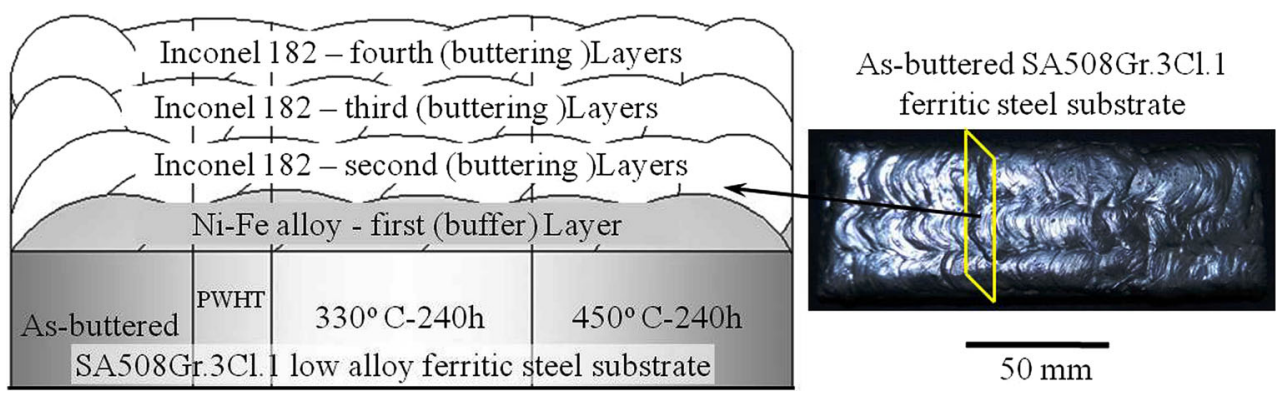

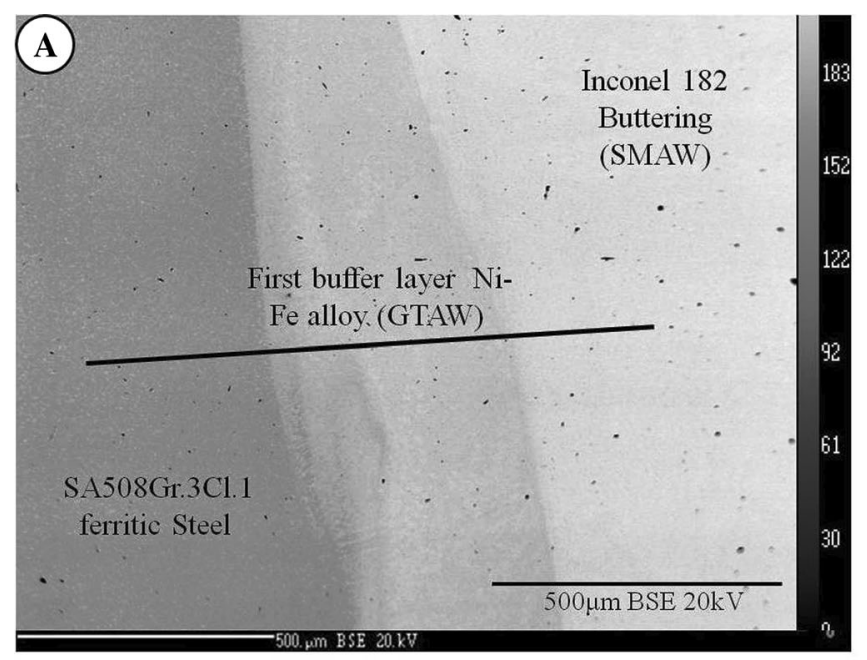

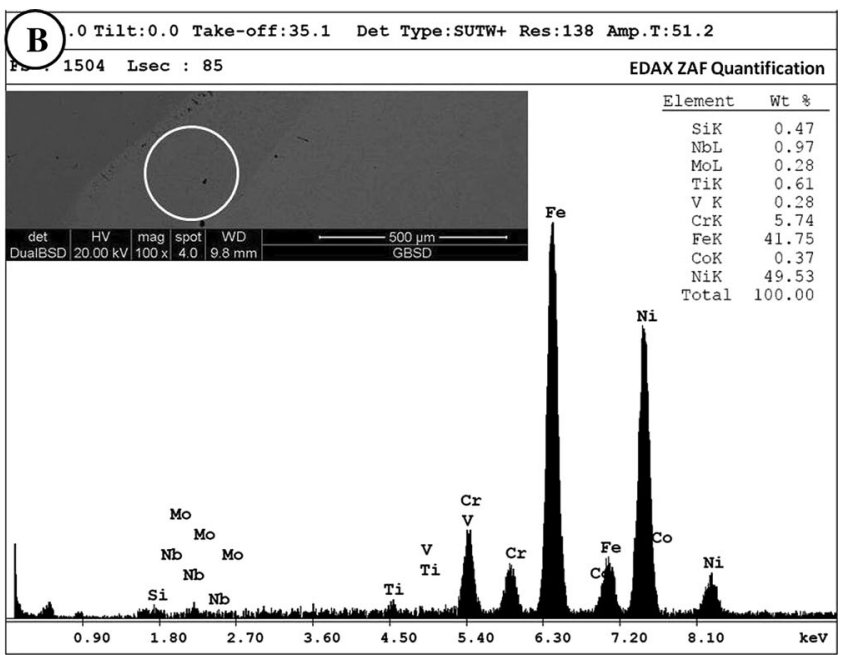

Fig. 2 (a) BSE image of EPMA traces covering spatial zones of weldment and (b) confirmation of composition in buffer layer by EDAX

Table 3 Confirmation and validation of OES results using EPMA

\begin{tabular}{llllll}
\hline EPMA (wt $\%)$ & & & & & $\begin{array}{l}\text { Optical emission } \\
\text { spectrometry (OES) (wt\%) }\end{array}$ \\
\cline { 1 - 3 } Element & Pt-1 & Pt-2 & Pt-3 & Avg. & \\
\hline $\mathrm{C}$ & - & - & - & - & $\mathbf{0 . 0 4 2}$ \\
$\mathrm{Cr}$ & 14.07 & 13.49 & 14.10 & $\mathbf{1 3 . 8 8}$ & $\mathbf{1 3 . 6 4}$ \\
$\mathrm{Ni}$ & 61.39 & 60.19 & 61.98 & $\mathbf{6 1 . 8 6}$ & $\mathbf{6 1 . 8 1}$ \\
$\mathrm{Fe}$ & 11.83 & 11.01 & 11.61 & $\mathbf{1 1 . 4 8}$ & $\mathbf{1 1 . 1 8}$ \\
$\mathrm{Nb}$ & 1.83 & 1.91 & 1.47 & $\mathbf{1 . 7 4}$ & $\mathbf{1 . 7 7}$ \\
\hline
\end{tabular}

Bold values are the values which were compared with each other and used in analysis. Values which are not in bold are the set points from which the average has been taken
The backscatter electron (BSE) image (Fig. 2a) with horizontal black line indicates the traces of electron probe microanalysis (EPMA) started from ferritic steel to Inconel 182 buttering layer passing through $\mathrm{Ni}-\mathrm{Fe}$ buffer layer and that covers the all three spatial zones of different materials. The data obtained from EPMA in buffer layer were also confirmed with energy-dispersive X-ray spectroscopy using ZAF algorithm (in agreement) as shown in Fig. 2b. Optical emission spectrometry (OES) was adopted for measurement of chemical compositions in base metal, filler metals, and weld pads of different heat-treated conditions. The result obtained from OES (average of three counts) on the surface of as-buttered specimen was confirmed and validated with average of three counts of EPMA on the same location and specimen and that is given in Table 3 . The OES composition was measured three counts for the all measurements in study.

The microstructure of SA508Gr.3cl.1 ferritic steel was revealed with $2 \%$ nital solution. Ni-base microstructure (buffer and buttering layers) evolution was made with $10 \%$ ammonium persulfate electrolyte etch at $6 \mathrm{~V}$ for 30-60 s. The Vickers microhardness across the weld regions was measured by adopting the procedure given in ASTM E38402 standard using $100 \mathrm{gf}$ (in bulk material zone) and $10 \mathrm{gf}$ (at interfacial regions) loads. The existence of undesirable phases was confirmed with X-ray diffraction (XRD) 
analysis using a thin-film X-ray diffractometer for the buttering deposit, and the results were analyzed by JCPDSICDD software.

\section{Results and Discussion}

\section{Weld Chemistry and Carbon Diffusion}

The chemical composition in each buffer and buttering layer of as-buttered and thermally aged specimens measured with OES is given in Table 4. Interstitial diffusion may cause during thermal aging $\left(330\right.$ and $450{ }^{\circ} \mathrm{C}$ ) for specified time of $240 \mathrm{~h}$, while substitutional diffusion would not occur at these temperatures. Therefore, the values of carbon concentrations were considered for the calculation of diffusion coefficient of carbon from ferritic steel to buffer layer and so on. Diffusion of carbon involves decomposition of carbides in SA508 ferritic steel, and diffusion of carbon from ferritic steel to $\mathrm{Ni}-\mathrm{Fe}$ alloy/Inconel 182 buttering may take place at interfaces. This can form decarburized soft zone and can be identified with optical microscope [2, 10].

The driving force for diffusion is the activity gradient between low $\mathrm{Cr}$ content (SA508 ferritic steel) and high $\mathrm{Cr}$ content (Inconel 182). This carbon activity gradient between two materials cannot be described by carbon concentration only [2]. As the $\mathrm{Ni}-\mathrm{Fe}$ matrix has no $\mathrm{Cr}$ or other carbide formers like Inconel 182, so the activity gradient for diffusion of carbon from ferritic steel to buffer layer will be less but exists due to $\mathrm{Fe}$ content in matrix. Hence, the dissolution of carbides in heat-affected zone (HAZ) of ferritic steel would occur during welding and that may cause marginal diffusion of carbon from ferritic steel. The carbon activity gradient due to varying $\mathrm{Cr}$ content in $\mathrm{Ni}-\mathrm{Fe}$ buffer layer and Inconel 182 buttering layer could exist, but concentration of carbon in both layers is also important concern. Considering these mechanisms, the reasonably accurate diffusion couple developed by Groube can be effectively used [16] for the estimation of diffusion coefficient of carbon from ferritic steel to buttering layers.

The Groube integration assumes that the concentration gradient is symmetrical about an interface between two components and that the diffusion coefficient does not vary essentially with concentration [16]. This assumption is reasonably acceptable in small concentration gradient system. In the present study, the ferritic steel, buffer layer, and buttering layers exist with small concentration gradient (significant with buffer layer to buttering layer) and activity gradient. It was also assumed that, during thermal aging, the composition of layers forming the diffusion couple would remain constant independent of layer thickness [16] (as there no substitutional diffusion is possible). This assumption is valid for as-buttered condition and thermal aging [16]. The diffusivity of carbon [16, 22-27] was determined using Groube solution (Eq. 1) for diffusion couple.

$C_{(x, t)}-C_{1}=\frac{C_{2}-C_{1}}{2}\left[1-\operatorname{erf}\left(\frac{x}{2 \sqrt{D t}}\right)\right]$

where $C_{(x, t)}$ is the known weight percentage of carbon, $C_{2}$ is the higher concentration of carbon, and $C_{1}$ is the lower concentration of carbon. $D$ represents the diffusivity of carbon in $\mathrm{m}^{2} / \mathrm{s}, x$ is the distance in meter $(\mathrm{m})$ at which measurement was taken, and $t$ is the time in seconds (s). The welding data were recorded during buttering, and the

Table 4 Chemical composition in buffer and buttering layers of as-buttered and thermally aged condition of specimens

\begin{tabular}{|c|c|c|c|c|c|c|c|c|}
\hline \multirow[t]{2}{*}{ Condition } & \multicolumn{8}{|c|}{ Elemental composition in weight percentage (wt $\%$ ) } \\
\hline & Layer & $\mathrm{C}$ & $\mathrm{Cr}$ & $\mathrm{Ni}$ & $\mathrm{Fe}$ & $\mathrm{Mn}$ & $\mathrm{Nb}$ & Mo \\
\hline \multirow[t]{4}{*}{ As-buttered condition } & Ni-Fe layer (GTAW) & 0.025 & 0.15 & 49.03 & 49.05 & 0.89 & - & - \\
\hline & Second layer (SMAW) & 0.044 & 12.21 & 68.70 & 13.67 & 3.47 & 1.45 & 0.07 \\
\hline & Third layer (SMAW) & 0.042 & 12.56 & 65.65 & 12.59 & 3.56 & 1.48 & 0.04 \\
\hline & Fourth layer (SMAW) & 0.042 & 13.64 & 61.81 & 11.18 & 3.58 & 1.77 & 0.04 \\
\hline \multirow[t]{4}{*}{ Thermally aged at $330{ }^{\circ} \mathrm{C}$ for $240 \mathrm{~h}$} & $\mathrm{Ni}-\mathrm{Fe}$ layer (GTAW) & 0.036 & 0.16 & 50.11 & 48.95 & 0.51 & - & - \\
\hline & Second layer (SMAW) & 0.049 & 13.31 & 68.77 & 13.61 & 3.33 & 1.43 & 0.06 \\
\hline & Third layer (SMAW) & 0.043 & 13.18 & 66.08 & 12.76 & 3.59 & 1.56 & 0.05 \\
\hline & Fourth layer (SMAW) & 0.041 & 13.99 & 62.35 & 11.13 & 3.80 & 1.84 & 0.05 \\
\hline \multirow[t]{4}{*}{ Thermally aged at $450{ }^{\circ} \mathrm{C}$ for $240 \mathrm{~h}$} & Ni-Fe layer (GTAW) & 0.061 & 0.17 & 49.74 & 49.07 & 0.61 & - & - \\
\hline & Second layer (SMAW) & 0.051 & 12.13 & 68.66 & 13.93 & 3.45 & 1.77 & 0.04 \\
\hline & Third layer (SMAW) & 0.045 & 13.14 & 65.73 & 12.35 & 3.63 & 1.36 & 0.05 \\
\hline & Fourth layer (SMAW) & 0.043 & 14.21 & 62.58 & 11.11 & 3.74 & 1.86 & 0.04 \\
\hline
\end{tabular}

Carbon (C) weight percentage has been considered more important for diffusion study as it is the basis for experimentation. Hence, the importance of carbon content highlighted with bold numbers 
thermal history using thermocouple was used for this analysis. The temperature in HAZ of ferritic steel was recorded to be more than $450{ }^{\circ} \mathrm{C}$ for $43 \mathrm{~min}$. Above this temperature, dissociation and precipitation of carbides would be possible [21]. Carbon diffusivity $(D)$ was determined using diffusion couple (Groube solution) for asbuttered and thermally aged conditions. The calculations were made with known time of $43 \mathrm{~min}$ in as-buttered condition (during welding) and $240 \mathrm{~h}$ for thermal aging. Then, the concentration of carbon (C) was measured as a function of diffusion distance $x$ with origin being taken at the crossover point. The concentration at a given position after the diffusion in thermally aged and as-buttered condition $C(x, t)$ and initial concentration $C 1$ and $C 2$ will yield the values from error function as in Eq. 1. From error function table $[22,28]$ with known $x$ (Table 2 layer thickness) and time $t$, the diffusivity of carbon $(D)$ can be determined using Eq. 1.

The activity gradient and diffusion rate of carbon in high Ni-matrix are slow. Use of one or more intermediate layers with progressively increasing content of carbide-forming elements can slow down the carbon diffusion and rate of soft zone formation [6]. Ni-base fillers cannot completely restrict the formation of soft zone [1], but it decreases the growth rate of soft zone formation [1,6]. Therefore, the $\mathrm{Ni}-\mathrm{Fe}$ buffer layer with subsequent Inconel 182 buttering layer could lead to the graded composition of progressively increasing content of carbide-forming elements. The calculated diffusivities of carbon $(D)$ from ferritic steel to each layer of buttering for as-buttered and thermally aged conditions are given in Table 5.

The carbon diffusion is not only the function of concentration; rather, activity gradient is the main concern for it. The diffusion occurred in opposite direction in third and fourth layer of buttering, and this is referred as 'inverse' diffusion. This is indication of 'uphill' diffusion, and a case of 'uphill' diffusion is even reported in the well-known Darkens experiment [2, 25]. During welding, solid and liquid diffusion (mainly mixing due to dilution) exhibits; therefore, the diffusivity is observed to be more in asbuttered condition than in the thermally aged conditions. The carbon diffusivity is less in $330{ }^{\circ} \mathrm{C}$ aged condition than
$450{ }^{\circ} \mathrm{C}$ aging. This indicates that carbon diffusion still exists even at service temperature range $330{ }^{\circ} \mathrm{C}$. Diffusivities of carbon for the same material zones prepared with GMAW [16] are marginally more than the investigated diffusivities in the present study. However, diffusivity $(D)$ in multicomponent system [29] is less than the diffusivities in the present study. Hence, the graded composition of Ni-Fe alloy with subsequent higher dilution can effectively contribute in controlling the diffusion of carbon from ferritic steel to Inconel 182 buttering.

\section{Martensite Formation and Estimation}

The variation in major alloying elements $(\mathrm{Cr}, \mathrm{Fe}$, and $\mathrm{Ni})$ across the interfaces using EPMA (as shown in Fig. 2a) and subsequent layers using OES is shown in Fig. 3. The SA508 ferritic steel and Inconel 182 have the steeper composition gradient for the alloying elements. This sharp composition gradient has been significantly reduced with $\mathrm{Ni}-\mathrm{Fe}$ buffer layer and can be seen in Fig. 3. The gentle gradient of gradually decreasing trend has been observed compared to the steeper gradient in previous results by GMAW [16] due to higher dilution of SMAW for buttering. The variations in chemical compositions of different materials were caused to have the same composition gradient [18] in partially mixed zone (PMZ) near the fusion interfaces. Within PMZ, changes in chemical composition increase the hardenability of deposits owing to formation of martensite as an effect of cooling rate during solidification $[1,16,18,20,30]$. Alloying elements such as $\mathrm{C}, \mathrm{Mn}$, $\mathrm{Ni}, \mathrm{Cr}$, and Mo were actively involved in formation of martensite. Due to limitation of EPMA, composition of major alloying elements was measured, while carbon, Mn, and Mo were not measured due to low concentration.

The composition of low-concentration elements was calculated by considering the dilution of major alloying elements (Fe and Ni) in PMZ using EPMA [16, 18, 20, 31]. Variations in dilution of $\mathrm{Ni}$ and $\mathrm{Fe}$ within PMZ were used along with nominal concentration of elements in ferritic steel and filler metals to calculate $\mathrm{C}, \mathrm{Mn}$, and Mo by back calculation $[16,18,20,30,31]$. The low-concentration elements $(\mathrm{C}, \mathrm{Mn}$, and Mo) were assumed to be mixed in

Table 5 Calculated diffusivities of carbon $(D)$ in each layer of buttering

\begin{tabular}{lcrr}
\hline Layer description & \multicolumn{2}{l}{ Diffusivity $(D)$ in $\mathrm{m}^{2} / \mathrm{s}$} & \\
\cline { 2 - 3 } & \multicolumn{1}{l}{ As-buttered } & $330^{\circ} \mathrm{C}$ aged & $450{ }^{\circ} \mathrm{C}$ aged \\
\hline Ferritic steel (SA508)—first buffer layer (Ni-Fe alloy) & $3.24 \times 10^{-11}$ & $6.24 \times 10^{-13}$ & $2.22 \times 10^{-12}$ \\
First layer (Ni-Fe alloy)—second layer (Inconel 182) & $1.19 \times 10^{-9}$ & $6.02 \times 10^{-12}$ & $\uparrow 6.49 \times 10^{-12}$ \\
Second layer (Inconel 182)—-third layer (Inconel 182) & $\uparrow 3.19 \times 10^{-10}$ & $\uparrow 4.56 \times 10^{-12}$ & $\uparrow 3.29 \times 10^{-12}$ \\
Third layer (Inconel 182)—fourth layer (Inconel 182) & $\uparrow 3.66 \times 10^{-11}$ & $\uparrow 1.64 \times 10^{-13}$ & $\uparrow 1.33 \times 10^{-12}$ \\
\hline
\end{tabular}

$\uparrow$ indicates inverse diffusion 
PMZ according to the dilution of major alloying elements. The variations in dilution $\left(D_{l}\right)$ were estimated using Eq. 2 by considering the EPMA trace composition.

$D_{l}=C_{P M Z}-C_{F M} / C_{B M}-C_{F M}$

where $D_{l}$ indicates dilution, $C_{P M Z}$ is the concentration of elements in PMZ, and $C_{F M}$ and $C_{B M}$ indicate the nominal concentration of elements in filler metals and base metal, respectively. The $C_{F M}$ and $C_{B M}$ values of major elements have measured with OES, while $C_{P M Z}$ values of elements were obtained from the EPMA as the data given in Fig. 3. The dilution in PMZ from OES and EPMA at every position for $\mathrm{Ni}$ and $\mathrm{Fe}$ for both interfaces is shown in Fig. 4a. The values of $\mathrm{C}, \mathrm{Mn}$, and Mo concentration were determined using Eq. 3.

$C_{P M Z}=D_{l} C_{B M}+\left(1-D_{l}\right) C_{F M}$

The entire concentration gradients of carbon have been estimated from ferritic steel to Inconel 182 buttering using measured dilutions and can be seen in Fig. $4 \mathrm{~b}$. It is the representation of carbon concentration across the spatial regions of ferritic steel, Ni-Fe alloy and Inconel 182 for maximum and minimum values of dilution. This entire concentration gradient is confirmed with gradient measured with OES and that was used for the calculation of diffusion coefficients $(D)$.

The martensite start $\left(M_{s}\right)$ temperature was estimated with the method provided by DuPont and Gooch [16, 18, 20, 31] using Eq. 4.

$$
\begin{aligned}
M_{s}\left({ }^{\circ} \mathrm{C}\right)= & 540-(497 \mathrm{C} \%+6.3 \mathrm{Mn} \%+36.3 \mathrm{Ni} \% \\
& +10.8 \mathrm{Cr} \%+46.6 \mathrm{Mo} \%)
\end{aligned}
$$

The known and estimated compositions were used to calculate $M_{s}$ temperature within PMZ. The calculated maximum and minimum $M_{s}$ temperature was plotted against the distance across buffer and buttering layer. The profile of $M_{s}$ temperature for both PMZ is shown in Fig. 5.

The martensite layer of $\sim 70 \mu \mathrm{m}$ at ferritic steel/ $\mathrm{Ni}-\mathrm{Fe}$ buffer layer interface was estimated, while it was $\sim 9 \mu \mathrm{m}$ for the buffer layer/buttering layer (Inconel 182) interface. The thickness of martensite is varied due to varying composition at both interfaces within PMZ. The martensite thickness for the same material regions is reported in earlier study [16] with GMAW instead of SMAW, and it is observed to be significantly less than present study at both
Fig. 3 Major alloying element variations-traces of EPMA at weld interfaces and OES in subsequent buttering layers
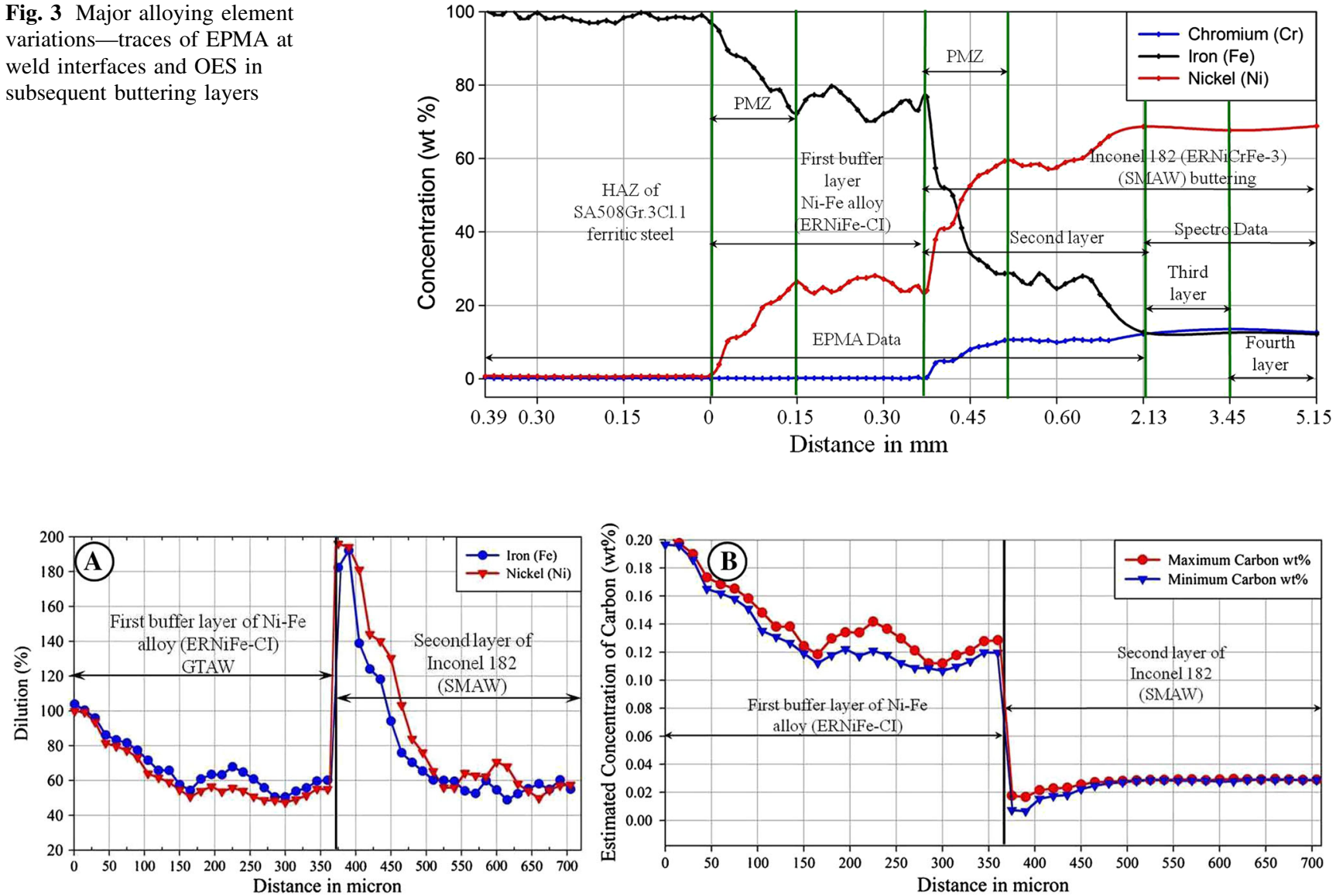

Fig. 4 Variations in spatial regions of materials for (a) calculated dilution of Fe and $\mathrm{Ni}$ and (b) estimated concentration gradients of carbon 
interfaces due to effect of dilution. The presence of martensite at both interfaces and its thickness has been confirmed with microhardness measurements and microstructure evolution and that can be seen in Fig. 6a, b. Figure $6 \mathrm{a}$ shows the interface microstructure and hardness for ferritic steel-buffer layer, while for buffer layer-Inconel 182 buttering it is shown in Fig. 6 b.

\section{Microhardness Variations Across the Interfaces}

The reformed martensite [11, 12, 32] fraction will remain in HAZ of ferritic steel which was auto-tempered due to multipass buttering procedure. The hardness profiles from SA508 ferritic steel to Inconel 182 buttering (second layer) through HAZ, interfaces and buffer layer are shown in Fig. 7 for as-buttered, thermally aged, and PWHT conditions. The instances of martensite formation within PMZ at interfaces can be observed in as-buttered and $330{ }^{\circ} \mathrm{C}$ thermally aged condition. Such instances are confirmed in Fig. 6 by interfacial hardness indentations. The estimated thicknesses of martensite $(\sim 70$ and $\sim 9 \mu \mathrm{m})$ at both interfaces are confirmed with marginal variations in Fig. 7.

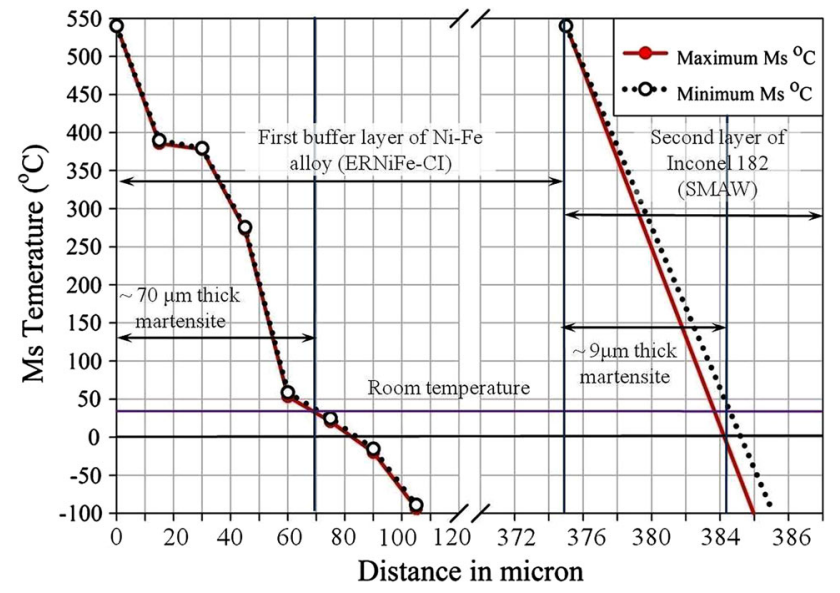

Fig. 5 Martensite start $\left(M_{s}\right)$ temperature (max. and min.) variations across the fusion interfaces of SA508 Gr.3Cl.1-Ni-Fe alloy and NiFe alloy-Inconel 182
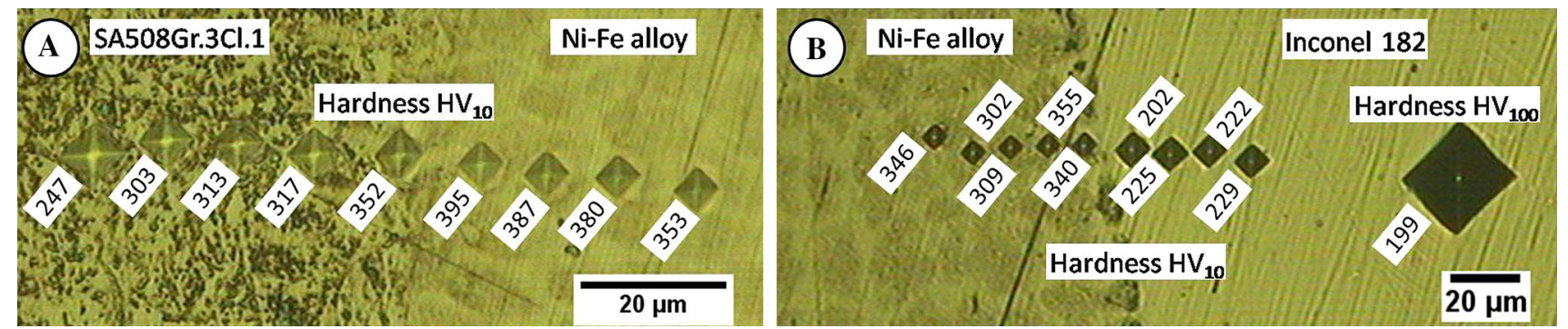

Fig. 6 Interfacial microhardness indentations and microstructures of (a) HAZ ferritic steel- Ni-Fe alloy and (b) Ni-Fe alloy- Inconel 182 buttering
The presence of carbon-enriched zone with reformed and tempered martensite could be present, and its reflection in terms of hardness is noticed in HAZ of ferritic steel and that is significant within $50 \mu \mathrm{m}$ distance from the interface. The thermal aging at $450{ }^{\circ} \mathrm{C}$ caused to temper the martensite (reduced hardness) in PMZ and buffer layer and that is more significant than $330{ }^{\circ} \mathrm{C}$ thermal aging but less significant than PWHT.

Hardness profile after PWHT was observed to be most favorable and indicates the tempering of martensite within PMZ and buffer layer, while reduced carbon activity and concentration gradient variation in terms of hardness owing to PWHT (risk of carbon migration) were also seen to be nonsignificant.

\section{Weldment Microstructure}

The as-received microstructure of SA508 ferritic steel is fully bainitic [11] with $\sim 25 \mu \mathrm{m}$ grain size. The coarse grain HAZ (CGHAZ) grain size $(\sim 15-20 \mu \mathrm{m})$ observed to be marginally smaller than base metal due to grain refinement caused by multipass buttering procedure and that can be seen in Fig. 8a.

The $\sim 30-\mu \mathrm{m}$-thick carbon-enriched zone suggests the presence of carbon activity; however, it confirms the nonmigration of carbon into buffer layer because of $\mathrm{Cr}$-free $\mathrm{Ni}-\mathrm{Fe}$ matrix. Some previous studies $[2,10,11]$ were showed the soft zone (white phases) formation in HAZ ferritic steel due to carbon migration. Comparing with present study, the carbon-enriched zone was revealed owing to retardation of carbon migration. Buffer layer microstructure was absent with Type-II and Type-I boundaries, while it is fully columnar and cellular dendritic from the fusion interface as shown in Fig. 8b. The columnar and cellular (martensitic nature) dendrite structure shows the $\sim 80-100 \mu \mathrm{m}$ thickness from the interface and that is in agreement with the estimated martensite $(\sim 70 \mu \mathrm{m})$ thickness and the hardness (Fig. 7).

The Fe-Ni-C system martensite observed to be different than $\mathrm{Fe}-\mathrm{C}$ system martensite and that can be confirmed with Fig. 9. Figure 9a shows the buffer layer martensitic 


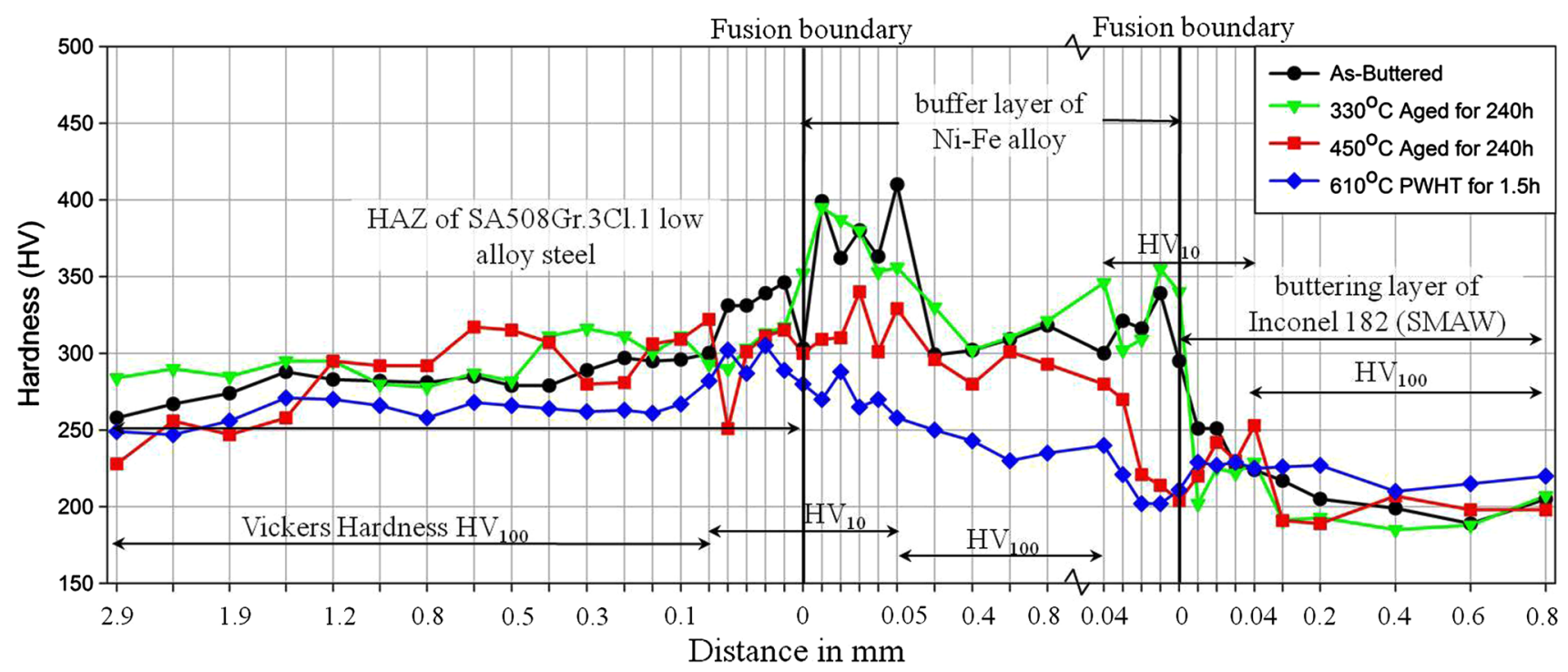

Fig. 7 Microhardness measurement across the fusion interfaces including HAZ SA508Gr.3cl.1, buffer layer (Ni-Fe alloy) and second buttering layer of Inconel 182
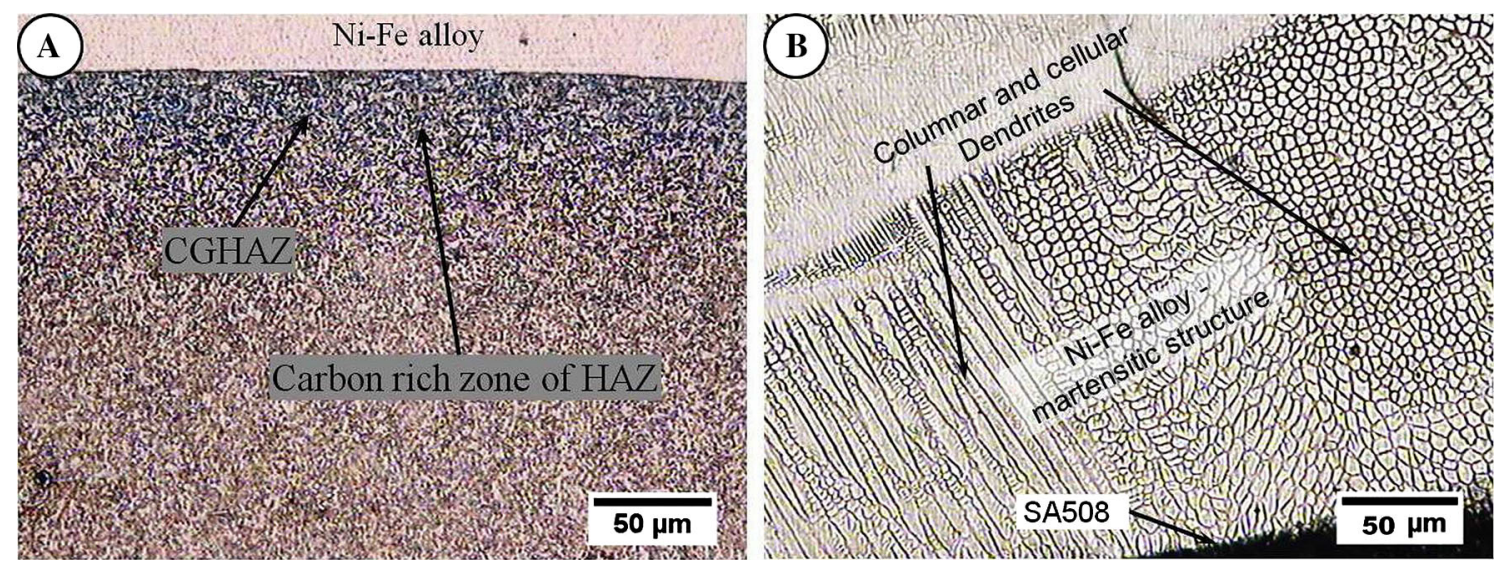

Fig. 8 Microstructure of (a) CG bainitic HAZ and carbon-enriched zone of ferritic steel near interface and (b) interior of Ni-Fe buffer layer showing columnar and cellular dendritic structure of martensitic nature
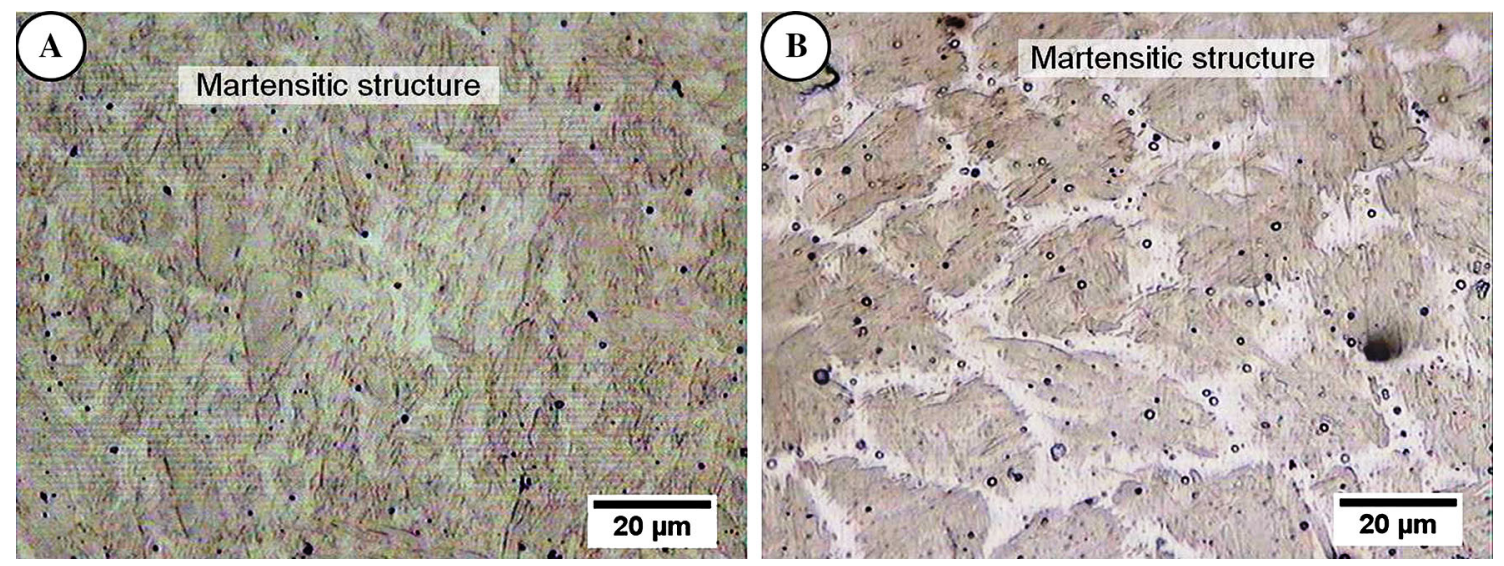

Fig. 9 Microstructure of Ni-Fe buffer layer (a) in as-buttered condition and (b) $450{ }^{\circ} \mathrm{C}$ thermally aged condition 
structure in as-buttered condition, while Fig. 9b shows the $450{ }^{\circ} \mathrm{C}$ thermally aged microstructure. This microstructure observed to be tempered with $\sim 20 \mu \mathrm{m}$ grain size which was marginally more than the grain size $(\sim 12-18 \mu \mathrm{m})$ in as-buttered condition.

Fine secondary phase particles are also shown in Fig. 9a, b. The $\alpha$-Fe could not really exist in such chemistry, and therefore, the presence of martensite was confirmed with XRD in buttering deposit. Figure 10 shows the XRD peaks of $\gamma(\mathrm{Fe}, \mathrm{Ni})$ austenite with different diffracted planes in buffer and buttering layer (encircled section for test), while $\alpha$ ' with different diffracted planes [33] was also present in deposit which confirms the presence of martensite.

Figure $11 \mathrm{a}, \mathrm{b}$ shows the microstructure of Inconel 182 in fourth layer in as-buttered and $450{ }^{\circ} \mathrm{C}$ thermally aged condition, respectively. In the cellular dendritic region, the subgrains are lying parallel to the columnar structure. Laves phase presence has been evidenced along the grain boundary (indicated by arrows) in Fig. 11a. The secondary

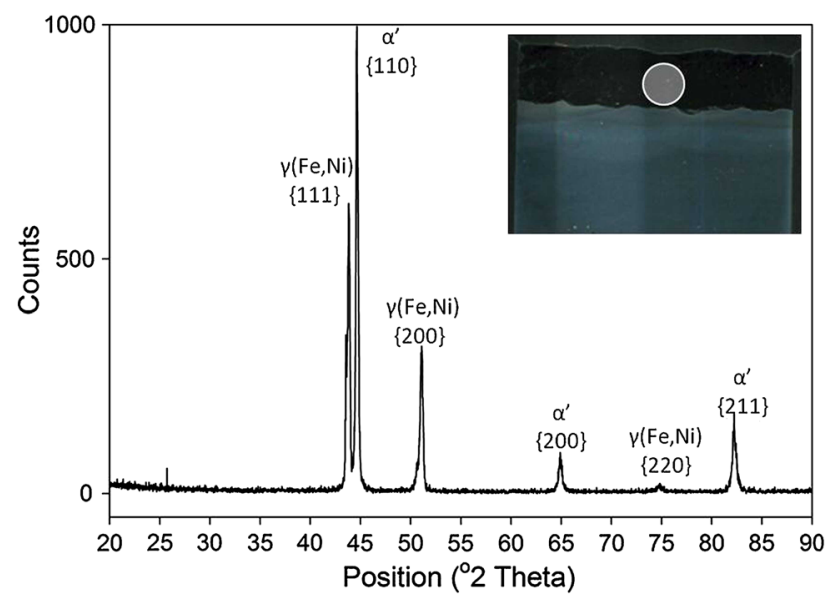

Fig. 10 XRD peaks for buttering deposits in as-buttered condition with location of test

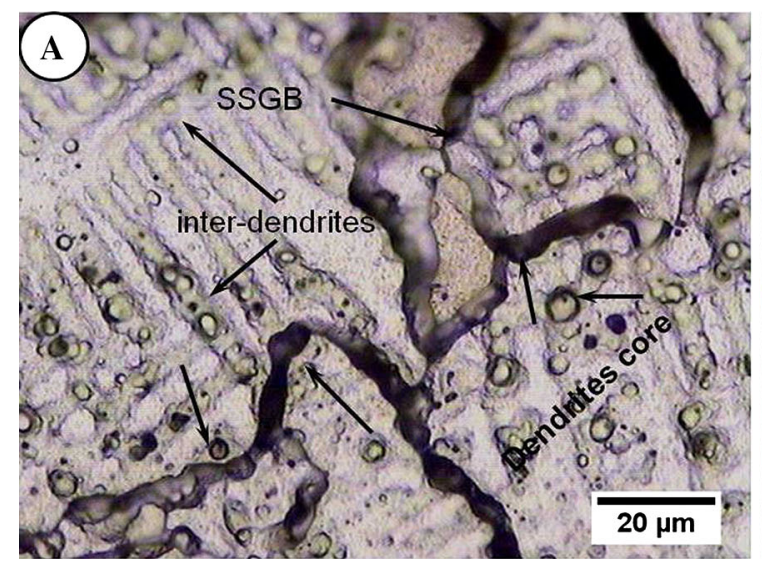

phase precipitates in Fig. $11 \mathrm{~b}$ are finely dispersed within subgrain structure owing to thermal aging. The size of such particles is observed to be smaller than as-buttered condition. These precipitates $[11,12,16]$ belong to $\mathrm{NbC}$ and TiC, but their continuous network was not noticed in both conditions. The Fe content in buttering deposit is more (dilution with $\mathrm{Ni}-\mathrm{Fe}$ alloy and initial composition of Inconel 182), which leads to decrease the $\mathrm{Nb}$ and $\mathrm{Ti}$ solubility in austenite phase. Hence, their ability to remain in solid solution became limited [34]. Significant content of $\mathrm{Nb}$ and $\mathrm{Ti}$ along with high content of $\mathrm{Fe}$ in solution would cause to increase partitioning of $\mathrm{Nb}$ and $\mathrm{Ti}$ in interdendritic region [34], and as a result, $\mathrm{NbC}$ and $\mathrm{TiC}$ formation would become easier. Hence, some fraction of $\mathrm{NbC}$ (dark) and TiC (shiny) were observed in buttering deposit and are indicated by arrows in Fig. 11a, b. Due to less intensity in deposits, their counts have not noticed with XRD.

\section{Conclusion}

Based on analysis of the obtained results, following conclusions have been derived which suggests the economic choice of SMAW buttering procedure.

1. Ni-Fe alloy in terms of graded composition can effectively control the concentration and activity gradient of carbon.

2. Inverse/uphill diffusion is confirmed in buttering layer due to Ni-Fe buffer layer; hence, migration of carbon from ferritic steel to Inconel 182 can be arrested.

3. Carbon diffusivity observed to be more in as-buttered condition than in thermally aged condition owing to dilution effect. However, the very slow diffusion of carbon would even take place at service temperature (310-330 $\left.{ }^{\circ} \mathrm{C}\right)$.

4. Approximately, 30- $\mu$ m-thick carbon-enriched zone in HAZ ferritic steel interface is exhibited. This suggests

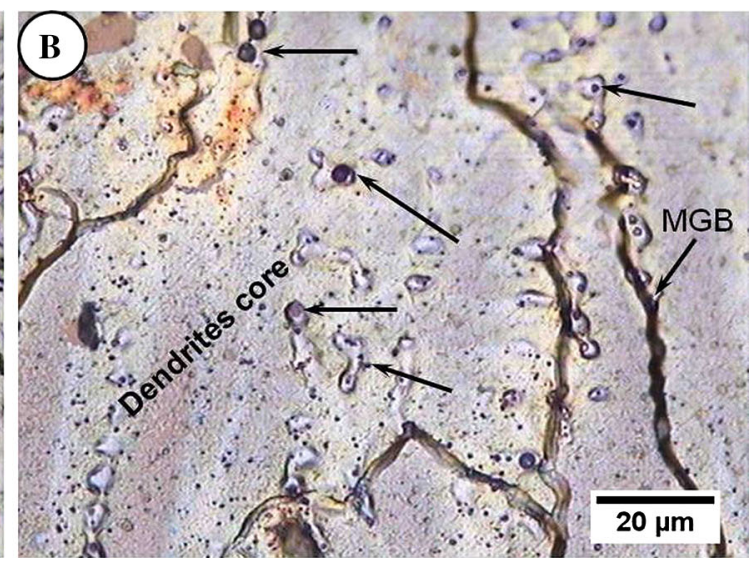

Fig. 11 Microstructure in fourth buttering layer (Inconel 182) for (a) as-buttered and (b) $450{ }^{\circ} \mathrm{C}$ thermally aged condition 
the presence of carbon activity gradient but absence of carbon diffusion due to saturation of carbon (carbonenriched zone) near the interface.

5. Chemistry mismatch in PMZ of ferritic steel/Ni-Fe alloy caused to form $\sim 70$ - $\mu$ m-thick martensite, while other weld chemistry at PMZ of Ni-Fe alloy/Inconel 182 was estimated with $\sim 9-\mu \mathrm{m}$ martensite. The most favorable hardness profile was found with PWHT specimen.

6. Martensitic structure in PMZ and buffer layer is almost columnar and cellular dendritic of $\mathrm{Fe}-\mathrm{Ni}-\mathrm{C}$ type and that is greatly depending on the extent of dilution. Metallurgical deterioration in terms of Type-II boundary formation was not evidenced. The increased Fe content in buttering deposit affects the solubility of $\mathrm{Nb}$ and $\mathrm{Ti}$ in matrix and caused to form small fraction of fine precipitates of $\mathrm{NbC}$ and $\mathrm{TiC}$ in the Inconel 182 matrix.

7. SMAW for buttering procedure can inveterate the economic changeover against the expensive and timeconsuming GTAW process on the basis of diffusion and metallurgical properties.

\footnotetext{
Acknowledgments Authors acknowledge the support given by Board of Research in Nuclear Sciences, Department of Atomic Energy (India), for present work (2008/36/107-BRNS/4038A). Authors also thankfully acknowledge the Defense Metallurgical Research Laboratory, Hyderabad (Ministry of Defense, India), for facilitating EPMA, EDAX and XRD facility in diffusion-related study.
}

Open Access This article is distributed under the terms of the Creative Commons Attribution 4.0 International License (http://crea tivecommons.org/licenses/by/4.0/), which permits unrestricted use, distribution, and reproduction in any medium, provided you give appropriate credit to the original author(s) and the source, provide a link to the Creative Commons license, and indicate if changes were made.

\section{References}

1. C.D. Lundin, Dissimilar metal welds-transition joint literature review. Weld. Res. Suppl. 61, 58s-63s (1982)

2. F. Mas, C. Tassin, N. Valle, F. Robaut, F. Charlot, M. Yescas, F. Roch, P. Todeschini, Y. Bréchet, Metallurgical characterization of coupled carbon diffusion and precipitation in dissimilar steel welds. J. Mater. Sci. 51, 4864-4879 (2016)

3. R. Miteva, N.G. Taylor, General Review of Dissimilar Metal Welds in Piping Systems of Pressurised Water Reactors, Including WWER Designs, NESC Report (Institute for Energy, Netherland, 2006)

4. N. Taylor, C. Faidy, P. Gilles, Assessment of Dissimilar Weld Integrity: Final Report of the NESC-III Project (Institute for Energy, European Commission, DG-Joint Research Centre, 2006)

5. C. Sudha, A.L.E. Terrance, S.K. Albert, M. Vijayalakshmi, Systematic study of formation of soft and hard zones in the dissimilar weldments of Cr-Mo steels. J. Nucl. Mater. 302, 193-205 (2002)
6. Y.Y. Ying, S.R. Kae, S.R. Haur, C. Chun, The study of carbon migration in dissimilar welding of the modified $9 \mathrm{Cr}-1 \mathrm{Mo}$ steel. J. Mater. Sci. Lett. 20, 1429-1432 (2001)

7. C. Sudha, V.T. Paul, A.L.E. Terrance, S. Saroja, M. Vijayalakshmi, Microstructure and microchemistry of hard zone of dissimilar weld of Cr-Mo steel. Weld. J. 85, 71s-80s (2006)

8. R. Anand, C. Sudha, V.T. Paul, S. Saroja, Microstructural changes in Grade 22 ferritic steel clad successively with Ni-based and 9Cr filler metals. Weld. J. 89, 65s-74s (2010)

9. A.K. Bhaduri, S. Venkadesan, P. Rodriguez, P.G. Mukunda, Transition metal joints for steam generators-an overview. Int. J. Press. Vessels Pip. 58, 251-265 (1994)

10. J. Frei, B.T. Alexandrov, M. Rethmeier, Low heat input gas metal arc welding for dissimilar metal weld overlays part I: the heataffected zone. Weld. World 60, 1-15 (2016)

11. D.W. Rathod, S. Pandey, P.K. Singh, R. Prasad, Experimental analysis of dissimilar metal weld joint: ferritic to austenitic stainless steel. Mater. Sci. Eng. A 639, 259-268 (2015)

12. D.W. Rathod, S. Pandey, P.K. Singh, R. Prasad, Mechanical properties variations and comparative analysis of dissimilar metal pipe welds in pressure vessel system of nuclear plants. J. Press. Vessel Technol. 138, 011403 (2016)

13. D.W. Rathod, Weldability Investigations of Dissimilar Metal Joints for Nuclear Plant Applications. Ph.D. Doctoral Thesis (Department of Mechanical Engineering, IIT Delhi, New Delhi, Jan 2015)

14. S. Pandey, R. Prasad, P.K. Singh, D.W. Rathod, Investigation on Dissimilar Metal Welds of SA312 Type 304LN Pipe (extruded) and SA508Gr.3Cl.1 Pipe (forged) (Bhabha Atomic Research Centre, Mumbai 2008/36/107-BRNS/4038A, Dec 2014)

15. M. Sireesha, V. Shankar, S.K. Albert, S. Sundaresan, Microstructural features of dissimilar welds between $316 \mathrm{LN}$ austenitic stainless steel and alloy 800. Mater. Sci. Eng. A 292, 74-82 (2000)

16. D.W. Rathod, S. Aravindan, P.K. Singh, S. Pandey, Metallurgical characterization and diffusion studies of successively buttered deposit of Ni-Fe alloy and Inconel on SA508 ferritic steel. ISIJ Int. 54, 1866-1875 (2014)

17. D.W. Rathod, P.K. Singh, S. Pandey, S. Aravindan, Effect of buffer-layered buttering on microstructure and mechanical properties of dissimilar metal weld joints for nuclear plant application. Mater. Sci. Eng. A 666, 100-113 (2016)

18. J.N. Dupont, C.S. Kusko, Technical note: martensite formation in austenitic/ferritic dissimilar alloy welds. Weld. J. 86, 51s-54s (2007)

19. J.N. DuPont, S. Babu, S. Liu, Welding of materials for energy applications. Metall. Mater. Trans. A 44A, 3385-3410 (2013)

20. J.N. DuPont, R.E. Mizia, Review of Dissimilar Metal Welding for the NGNP Helical Coil Steam Generator (Idaho National Laboratory, Idaho Falls, Idaho INL/EXT-10-18459, March 2010)

21. S.S. Babu, Classifications and mechanisms of steel transformation, in Steel Heat Treatment: Metallurgy and Technologies, 2nd edn., ed. by G. Totten (CRC Press, Taylor and Francis Group, New York, 2007), pp. 91-118

22. V. Raghavan, Solid State Phase Transformations, First, Edition edn. (Prentice Hall of India, New Delhi, 1987)

23. D.A. Porter, K.E. Esterling, M.Y. Sherif, Phase Transformations in Metals and Alloys, 3rd edn. (CRC Press, Taylor and Francis Group, New York, 2009)

24. L.S. Darken, R.A. Oriani, Thermal diffusion in solid alloys. Acta Metall. 2, 841-847 (1954)

25. L.S. Darken, Diffusion of Carbon in Austenite with a discontinuity in composition, in Trans AIME, 1948, Issued as TP 2443 in Metals Technology, pp. 430-438, October 1948

26. V.M. Falchenco, L.N. Larikov, V.R. Ryabov, Diffusion Processes in Solid-Phase Welding of Materials, 1st edn. (Oxonian Press, New Delhi, 1984) 
27. S.K. Bose, H.J. Grabke, Diffusion coefficient of $\mathrm{C}$ in $\mathrm{Fe}-\mathrm{Ni}$ austenite in the temperature range of $950-1100{ }^{\circ} \mathrm{C}$. Z . Metall. 69(1), 8-15 (1978)

28. M.E. Glicksman, Diffusion in Solids: Field Theory, Solid-State Principles, and Applications, 1st edn. (Wiley-Interscience, New York, 1999)

29. J. Cermak, L. Kral, Carbon diffusion in carbon-supersaturated ferrite and austenite. J. Alloys Compd. 586, 129-135 (2014)

30. Z.R. Chen, Y.H. Lu, TEM observation of martensite layer at the weld interface of an A508III to Inconel 82 dissimilar metal weld joint. Metall. Mater. Trans. A 46, 5494-5498 (2015)

31. J.N. Dupont, S.W. Banovic, A.R. Marder, Microstructural evolution and weldability of dissimilar welds between a super austenitic stainless steel and nickel-based alloys. Weld. J. 82(6), $125 \mathrm{~s}-135 \mathrm{~s}$ (2003)

32. G. Srinivasan, A.K. Bhaduri, Development of Transition metal joints for steam generator applications, in Proceedings of 63rd Annual Assembly \& International Conference of the International Institute of Welding, Istanbul, Turkey, July 2010, pp. 81-87

33. G. Zepon, C.S. Kiminami, W.J. Botta Filho, C. Bolfarini, Microstructure and wear resistance of spray-formed supermartensitic stainless steel. Mater. Res. 16, 642-646 (2013)

34. H. Naffakh, M. Shamanian, F. Ashrafizadeh, Influence of artificial aging on microstructure and mechanical properties of dissimilar welds between 310 stainless steel and INCONEL 657. Metall. Mater. Trans. A 39A, 2403-2415 (2008) 